\title{
Ernesto Laclau and Critical Media Studies: Marxism, Capitalism, and Critique
}

\author{
Jannick Schou
}

\author{
IT University of Copenhagen, Copenhagen, Denmark, janh@itu.dk
}

\begin{abstract}
Ernesto Laclau's post-Marxist discourse theory is increasingly utilised within media studies in order to investigate discourses circulating about, within, and through media. Discourse theory has proved itself to be a productive theoretical asset that can yield important empirical insights into the solidification and neutralisation of particular discursive regimes. Yet, the critical potentials of Laclau's theoretical work have often been downplayed or neglected. Instead of offering a fully formed critical theory, Laclau has been relegated to offering a descriptive toolbox in which the underlying critical implications have been either overlooked or forgotten altogether. This paper seeks to reflect on the potentials and obstacles within Laclau's work for critical media studies by engaging with the role of Marxism, capitalism and critique. First, the paper addresses the relation between Marxism and postMarxism by arguing that rather than abandoning Marxism, Laclau actively situates his own work as a dialogue with and against this tradition. Second, the paper addresses the relation between Laclau's analysis of so-called globalised capitalism and political struggle, which leads to a discussion of class relations and political economy. Third, the paper examines Laclau's notion of ideology critique and argues that it must be seen as a simultaneously explanatory, normative and practical perspective. Based on these discussions, it is this paper's contention that it is insufficient to simply appropriate discourse theory as a descriptive research format, but that it must rather be seen as underlined by a radical critique of existing structures of domination and capitalist subordination. The paper furthermore argues that there are parts of Laclau's work that are problematic for this purpose and needs to receive further attention by future research. By providing an extended discussion of Laclau's own work, this paper seeks to contribute to the critical application of discourse theory within the field of media studies and contribute to the on-going dialogue between Marxism, post-Marxism, and critical media studies.
\end{abstract}

Keywords: Ernesto Laclau, post-Marxism, critique, discourse theory, capitalism, Marxism, critical media studies

Acknowledgements: I would like to thank Johan Farkas for his helpful suggestions on the first draft of this paper as well as both reviewers and the editor for their highly productive comments.

\section{Introduction: Laclau and Media Studies}

Ernesto Laclau's $(1990,2005)$ post-Marxist discourse theory has slowly but surely made its entrance into the field of media studies during the last two decades (Dahlberg and Phelan 2011). Throughout his many writings, Laclau $(1979,1990,1996,2014)$ developed a form of Marxism that does not rest on nor takes its point of departure in a priori class relations or economic base structures. Rather, Laclau developed, at times together with Chantal Mouffe, a political theory of signification that is often refereed to as discourse theory. Discourse theory stresses the fixation of meaning into particular regimes as the outcome of continuous and contingent discursive struggles taking place over time. By reconfiguring Gramsci's (2005) notion of hegemony, Laclau (1990) has provided a rich theoretical corpus spanning both normative questions concerning the production of radical democracy (Laclau and Mouffe, 1985; see also Mouffe 2005, 2013) as well as a theory of populism and political transformation (Laclau 2005). Broadly construed, Laclau's work can be characterised as an antiessentialist approach to meaning that approaches it as socially constructed and necessarily contingent, while awarding a primary position to the political as the precarious and incomplete ground of the social (Laclau 1990; Howarth 2000; Marchart 2007). As Howarth and Stavrakakis $(2000,7)$ have argued, discourse theory "takes its lead from interpretative methods of social inquiry in which emphasis is placed on understanding and explaining the emer- 
gence and logic of discourses, and the socially constructed identities they confer upon social agents".

During the last few years, a number of authors have mobilised parts of Laclau's theory in order to investigate discourses circulating about, within, and through media (Dahlberg and Phelan 2011; Carpentier and Spinoy 2008). In the context of media and communication studies, this includes research on environmental activism (Askanius and Uldam 2011), Occupy Wall Street (Dahlgren 2013; Husted 2015), media professionals (Carpentier 2005), grassroots politics online (Schou, Farkas and Hjelholt 2015), right-wing extremist discourses (Kompatsiaris and Mylonas 2015; De Cleen 2015; Askanius and Mylonas 2015), documentaries on the war on terror (Mylonas 2012), and news media (Phelan 2009a, 2009b; Kumpu 2016; Mylonas 2014), to name but a few recent examples ${ }^{1}$. Within this body of work, discourse theory has shown itself to be a productive way of investigating the construction and solidification of particular political discourses into hegemonic projects. Not only has this research provided valuable insights into how cultural Others are produced as antagonised scapegoats (Askanius and Mylonas 2015), but it has also deconstructed how extremist and totalitarian logics work (Kompatsiaris and Mylonas 2015).

Supplementing this first and foremost empirical strand of research, there has also been a trajectory that has sought to model Laclau (and Mouffe's) discourse theory into a coherent theoretical framework that may be used for various kinds of empirical studies. In media studies, particularly Carpentier and De Cleen (2007, see also Carpentier 2010) have attempted such an approach ${ }^{2}$. While comparatively smaller in scope than the empirical studies, it seems that this approach has had considerable resonance within the field (see e.g. Kumpu 2016; Dahlgren 2011). These authors have sought to transform discourse theory into a systematic empirical framework named discourse-theoretical analysis (DTA) by coupling it with a qualitative research format and rearticulating core concepts into so-called 'sensitizing concepts' that point the researcher towards 'what to look for and where to look' (Carpentier and De Cleen 2007, 273).

Taken together, the empirical and theoretical trajectories highlight the growing appropriation of Laclau's work within the field of media studies. They showcase how Laclauian discourse theory, albeit still occupying a marginal position compared to e.g. Norman Fairclough's critical discourse analysis (Dahlgren 2011), is becoming an increasingly important approach. When reading this growing body of research, it is clear that discourse theory often provides an invaluable theoretical asset. Yet, at the same time, there is a relative absence of Marxist lines of critical inquiry. In being operationalised within the particularities of specific research contexts-activism, right-wing discourses, grassroots politics, and so on-the political implications and ambitions of discourse theory itself often takes a backseat. Discourse theory provides a series of useful concepts, yet normative questions, conceived within the context of this theory, are rendered less central ${ }^{3}$. Thus, while a number of the authors discussed above do engage in critical interventions, Laclau is very rarely used as part of these critiques. His work is relegated to offering a descriptive-analytical toolbox instead of a normative-political one. This leads, in many instances, to a situation comparable to Fenton's (2016, 347 ) recent critique of the study of digital media and radical politics: "We map and describe

\footnotetext{
${ }^{1}$ It should be stressed that the list of works mentioned here is in no way exhaustive and is limited to the last few years. I have furthermore chosen to focus on the (mostly) empirical translations of discourse theory, which means that studies combining theoretical and empirical research have been left out. The works collected in Dahlberg and Phelan (2011) are a good example of this combined empirical-theoretical approach (see e.g. Marchart 2011 or Fenton 2011). Finally, Laclau's influence on Stuart Hall (and vice versa) should also be mentioned as an important dialogue between post-Marxist discourse theory and cultural studies (see e.g Bowman 2007; Phelan and Dahlberg 2011, 7-8).

2 Outside media studies, authors such as Andersen (2003) and Jørgensen and Phillips (2002) have, albeit in different ways, attempted similar lines of theorising. The aim of these approaches have been to formalise the analytical categories found within discourse theory into coherent frameworks. In this regard, there has been a tendency to reduce discourses to 'merely' linguistic constructs, and the relation between discourse theory and Marxism has been systematically marginalised.

3 This resonates with a broader concern levelled by Phelan and Dahlberg that "with some notable exceptions [...] discourse theory is sometimes engaged with in a superficial way, consistent with what Hesmondhalg and Toynbee [...] suggests is the fragmentary and haphazard appropriation of social theory in media studies" $(2011,2)$.
} 
how activists communicate and neglect [...] the constraints that must be overcome and concrete feasible politics that must be developed in order to advance social change". The real challenge, according to Fenton, lies in the translation of such descriptions into the sphere of social change and political critique. This means developing a critical research approach that is simultaneously explanatory, practical, and normative, Fenton (2016) argues following the critical theory developed by Max Horkheimer (2002) and the Frankfurt School. In pursuing such a critical perspective, it remains of utmost importance not to depoliticise the political. As Fenton rightly asks: "How can we begin to tackle the challenges posed to democratic politics if we do not talk about actual politics as part of our research? This problem is both conceptual and practical. A politics requires a practice" $(2016,358)$. Though Fenton's critique is framed in a slightly different context (the field of mediated activism and protest at large), a very similar line of critique can be developed in the case of Laclau and critical media studies: Where did critical politics go? Where did normative visions go? And, additionally, where did Marxist politics go?

This paper seeks to reflect on and discuss the potentials and obstacles within Laclau's work for critical media studies, with an emphasis on Marxism, capitalism, and critique. The paper attempts to provide a renewed Marxist reading of Laclau that engages with and against his theoretical project in an attempt to showcase potential dialogues across postMarxism and Marxist media studies. Within the field of critical Marxist media studies, exemplified by critical authors like Christian Fuchs $(2008,2011)$, there has sometimes been a tendency to dismiss post-structuralist writers, such as Foucault, Butler, and (by extension) Laclau, for first and foremost being interested in de-essentialising essences and universal, while having no real politics, no idea about how society should or ought to be (see e.g. Fuchs $2011,29-43$ ). While this critique may apply in part to the other mentioned authors, the case is different with Laclau. Yet, this line of argumentation has often been greatly obscured, due, perhaps, to a lack of engagement with Laclau's own work, which has rendered potential interactions between post-Marxist and Marxist media studies problematic.

The basic argument developed in this paper will be that Laclau's work must be understood and contextualised within a distinctly Marxist tradition that is genuinely critical in the sense of being simultaneously explanatory, practical and normative. It is my contention that if we wish to utilise Laclau's work for critical media studies-which has rightly been suggested by a number of authors (Dahlberg and Phelan 2011) -, there is a need for a more open discussion and engagement with Laclau's own work and its critical potentials and obstacles.

As Dahlberg (2011) has rightly argued: "Given [...] [the] capitalist hegemony, and its clearly detrimental effects (from immiseration to environmental devastation), discourse theorists need to urgently prioritize the critical analysis of the current system, including [...] the ways in which media-communication technologies are supporting its hegemony, so as to bring to the fore obscured alternatives" (Dahlberg 2011, 55). But how can such a critique of capitalism be mobilised using Laclau's work? What would the role of Marxist politics be in such a critique? And what is the relation between crucial notions of contingency, political struggle, and normativity? By discussing these questions, this paper seeks to contribute to the growing body of work drawing on Laclauian discourse theory for critical media studies, while also adding to the on-going dialogue between Marxism, post-Marxism, and critical (media) research in a broader perspective (see e.g. Dahlberg 2014; Best 1999).

\section{Marxism and Post-Marxism: Thinking From Tradition}

Laclau arguably has what may be termed as an ambiguous relation towards Marxism, and (according to himself) he was never a "'total' Marxist" (Laclau 1990, 178). At the same time, Laclau also underlines that he never "rejected Marxism. Something very different has occurred. It's Marxism that has broken up and I believe I'm holding on to its best fragments" (Laclau 1990, 201). In order to capture this ambiguous stance in-between being a "total Marxist" and rejecting Marxism altogether, Laclau frequently employs the notion of postMarxism in order to describe his own theoretical work, emphasising how this theoretical perspective was formulated as a response to actual political practices and activist struggles in 
Argentina during the 1960s (Laclau 1990, 177-178, 197-198). From this perspective, it is no mere accident that Laclau and Mouffe (2014 [1985], xxi) open Hegemony and Socialist Strategy with the image of a crossroad: "Left-wing thought today stands at a crossroad". It is precisely by thinking through and within this crossroad that the basic theoretical project of discourse theory is to be located. But how, then, should we understand the notion of postMarxism? And how does Laclau reflect upon his relation to Marxism within his own work? These questions will be discussed in this section.

In 1977, in the introduction to his first book Politics and Ideology in Marxist Theory, Laclau (1979 [1977], 12) argued that what was needed was a "theoretical reformulation of Marxist categories", a reformulation that should provide the grounds for "the proletariat [...] to present itself as a hegemonic force to the vast masses seeking a radical political reorientation in the epoch of the world decline of capitalism". Though the revolutionary rhetoric employed in this early work is toned down during the course of Laclau's work, its basic contents can to a large extent be traced throughout his writings. Approximately ten years later, in 1987, Laclau and Mouffe (1990 [1987]) explicate the intellectual context of their joint work very clearly in their response to Norman Geras' (1987) critique of Hegemony and Socialist Strategy:

In our opinion, to rethink socialism [...] compels us to undertake two steps. The first is to accept, in all their radical novelty, the transformations of the world in which we live- that is to say, neither to ignore them nor to distort them in order to make them compatible with outdated schemas so that we may continue inhabiting forms of though which repeat the old formulae. The second is to start from this full insertion in the present-in its struggles, its challenges, its dangers-to interrogate the past: to search within it for the genealogy of the present situation; to recognize within it the presence-at first marginal and blurred —of problems that are ours; and, consequently, to establish with that past a dialogue which is organized around continuities and discontinuities, identifications and ruptures (Laclau and Mouffe 1990, 98).

In this response, which is in many ways emblematic of Laclau and Mouffe's approach at large, they underline that their theoretical work is to be situated within (what they term as) "a rethinking of socialism". According to Laclau and Mouffe, this rethinking requires two, overall steps. The first step concerns the development of theoretical concepts that can be used to understand and interpret social reality. What is called for here are theoretical 'schemas' that can be employed to adequately interpret existing conditions, rather than the reconfiguration of 'outdated' ones. This remark should first and foremost be seen as a critique of the Marxist tradition circulating during the 1960s and 1970s (see e.g. Laclau 1979, 12), with its reliance on what Laclau perceives as increasingly deterministic base-superstructure models (see also Laclau in Hansen and Sonnichsen 2014, 255).

In this sense, this step serves as a way of rectifying what Laclau and Mouffe observe as a tendency within the Marxist tradition to insist on fitting social reality within pre-existing theoretical models that have been rendered increasingly problematic. It is within the context of this step that a number of the theoretical components of discourse theory-articulation, discourse, hegemony, logic(s) of difference/equivalence, empty signifier, and so on-are to be located. They are ways of accepting and approaching the conditions of the present situation through adequate conceptual means.

The second step-the full insertion in the present to interrogate the past-should be read along the lines of a methodological imperative, holding at least a triple meaning. First, it can refer to a literal investigation of the historical conditions of emergence in which certain discourses have been able to fixate meaning in the present. It can, in other words, mean historicising the present. As Laclau has emphasised elsewhere, all discourses are characterised by what he terms radical historicity (Laclau 1990, 36), understood as the necessarily historical nature of all systems of meaning. Second, this step can also mean, in a sense not unlike Foucault's $(1991,31)$ history of the present, an interrogation of the past that is based on and takes its point of departure in present struggles and problems: in other words, a way of investigating the past through the struggles of the present. And third, this step can be interpreted 
in a self-referential manner as a description of the way in which any theoretical project must (in and of itself) be located within and through a historical tradition. To think the present-to phrase it somewhat differently-also means to think through the theoretical traditions of the past. The meaning of this third dimension-the thinking of the present through the traditions of the past-is important as it holds a number of implications for how the connection between Marxism and post-Marxism is to be approached.

When Laclau discusses Marxism, it is often within the context of a so-called radical political tradition of the West (see e.g. Laclau 1990, 179). This radical tradition, Laclau makes clear, includes several strands of intellectual thought, including Marxism and the Marxist tradition. In my view, Laclau's reliance on tradition as a central concept should first and foremost be seen as a way of displacing any focus on particular persons in favour of collective, intellectual endeavours. In this sense, whenever Laclau invokes Marxism, it is not so much the work of Marx, the person, as it is the collective intellectual tradition following Marx's work. Thus, the radical political tradition includes (but is not limited to) Marxism, while the Marxist tradition includes (but is not limited to) the work of Marx.

According to Laclau, it is precisely the radical tradition that should be revitalised. One way of doing this is by deconstructing the Marxist tradition. As Laclau argues elsewhere "as far as I am concerned, the deconstruction of the Marxist tradition, not its abandonment, is what proves important. The loss of collective memory is not something to be overjoyed about. It is always an impoverishment and a traumatic fact" (Laclau 1990,179). The loss of collective memory, the loss of tradition, is a traumatic fact according to Laclau. This also means that "one only thinks from a tradition" (Laclau 1990, 179, original emphasis). In this context, thinking from tradition implies a double movement in which the Marxist tradition is both something to be embraced and transformed: "the relation with tradition should not be one of submission and repetition, but of transformation and critique" (ibid.). In the last instance, this leads us right back to the crossroad discussed at the beginning of this section. As Laclau $(1990,179)$ makes clear: "Marxism's destiny as an intellectual tradition is clear: it will either be inscribed as a historical, partial, and limited moment within a wider historical line, that of the radical tradition of the West, or it will be taken over by the boy scouts of the small Trotskyist sects who will continue to repeat a totally obsolete language-and thus nobody will remember Marxism in twenty years' time".

Laclau opts quite explicitly for the former of these two choices, the inscription of the Marxist tradition within a renewed historical perspective. In choosing this trajectory, we can also begin to see how the notion of post-Marxism resurfaces. Framed in this perspective, postMarxism may be articulated as a way of historicising and de-essentialising the Marxist tradition by pushing contingency to the front. Or, in other words, an inscription of Marxist discourses within a renewed radical tradition. In this sense, discourse theory seeks to take "one step back" as Laclau puts it, in order to re-situate "Marxist theory within a horizon of broader interrogations which-without necessarily denying the former in its totality-relativizes and historicizes its categories" (Laclau 1990, 162).

This, in turn, seems to fully designate the transition from Marxism to post-Marxism: a transition that does not negate Marxism, but subsumes its categories as "specific historical forms within a wider universe of possible articulations" (Laclau 1990, 166). As Laclau and Mouffe make clear, this literally means that their theoretical stance is both post-Marxist and postMarxist: It is both that which comes after Marxism, but it is also located within Marxism and the Marxist tradition (Laclau and Mouffe 2014, xxiv). This, we should be clear, is imminently not an abandonment of this tradition. Rather, it is a genuine attempt not to turn Marx's work into an untouchable origin, "which contains within itself the seed of all future development" (Laclau and Mouffe 1990, 120), but instead engage actively with and against it.

Is Laclau a "Marxist" then? In my view, this question does not really capture what is at stake within his work. Primarily because Laclau would surely object to the notion of "Marxism" understood as a singular, enclosed, self-sufficient and objective trajectory of thought reducible to one particular system. If anything, Laclau's work shows how Marxism has been and continues to be an enormously heterogeneous and historically contingent notion prone to multiple and often diverging developments and interpretations. What is important, and this 
is precisely the claim I have tried to substantiate in this section, is the argument that Laclau does locate his own intellectual project within and against a Marxist tradition. This does not amount to saying whether or not Laclau was or was not a Marxist-whatever that may mean-but it does indicate that Marxism, understood as a certain political tradition of critical thought, plays a substantial role in providing the backdrop to Laclau's work. Rather than an abandonment of the Marxist legacy, post-Marxism should in my view be conceived as an attempted dialogue or bridge between Marxist, post-structuralist and deconstructionist currents.

If this is the case, then this has implications for the appropriation of Laclau's work, both in the context of media studies, but also in a broader perspective. It means that Laclau's theoretical enterprise cannot be thought apart from a certain intellectual and historical tradition ${ }^{4}$. Rather than merely a general theory of language, signification, and meaning that can be applied to this or that object of study, Laclau's discourse theory is imminently political in its origins: It is conceived - through and through-as a way of revitalising a particular historical tradition, namely (but not included to) Marxism. To think with and through discourse theory, it seems to me, is also to think with and through Marxism-post and otherwise.

\section{Capitalism: Struggle, Class and Political Economy}

In the above, I addressed the question of Marxism and post-Marxism by arguing that Laclau does not approach his own work as an abandonment of the Marxist tradition. On the contrary, I argued that Laclau quite explicitly frames his own work as an attempted renewal, revitalisation and transformation of this particular intellectual horizon. According to Laclau, it is by deconstructing existing theoretical categories, reimagining new ones, and being fully inserted in the present that the radical tradition can (and must) be kept alive. This argument runs throughout his entire oeuvre. If, indeed, this is the case, then the argument raised at the beginning of this paper-the somewhat absent presence of normative-political appropriations of Laclau's work-also becomes all the more puzzling.

Part of the reason for this relative absence may be that although Laclau does lay claim to a revitalisation of the Marxist tradition (a thinking through the cross-road of the Left), he deemphasises traditionally privileged Marxist concepts of capitalism, the economy, and class relations in his work. This displacement is often done through quite dense arguments, which do not, contrary to other parts of discourse theory, lend themselves to being operationalised easily within the context of empirical studies.

In this section, I discuss Laclau's (2005) conception of so-called globalised capitalism by interrogating its status as a theoretical construct, its relation to other central Laclauian concepts, and its operationalisation as an empirical tool. A core part of this section, then, will not only be to tease out Laclau's view on capitalism, but also, in a slightly more critical perspective, to problematise and scrutinise his arguments in order to bring forth the implications for critical media studies. This will lead into a discussion of class, materialism, and political economy that will highlight how Laclau's displacement of these concepts does (once again) not amount to abandoning Marxism.

\subsection{Globalised Capitalism}

In 2005, Laclau characterized the current political regime as a "qualitatively new stage in capitalist history" $(2005,231)$. He named this new stage globalised capitalism and defined it as "a complex in which economic, political, military, technological, and other determinations-each endowed with its own logic and a certain autonomy-enter into the determination of the movement of the whole" $(2005,230)$. According to Laclau (2005), the essence of this whole is heterogeneity rather than an "economic reality" (ibid.). Thus, in Laclau's conception of globalised capitalism, it is not a self-sufficient and closed system, which unfolds from

\footnotetext{
${ }^{4}$ Another way of approaching this question-the intellectual tradition to which Laclau belongs-would be to compare his work to other Marxists, such as e.g. Althusser, Žižek, Negri, and so on. Such an approach-which can partly be found in the works of Torfing (1999), Smith (1998), and Sim (2000)-is certainly productive, yet I wish to point towards the intellectual tradition of Laclau's work as articulated within the work itself.
} 
the internal tensions of an immanent logic (see also Laclau 1990, 55-57). Instead, Laclau offers a form of "capitalism [which] must be seen, in terms of its most fundamental and constitutive features, as a system of power" $(1990,56)$. If this system of power does manage to (partially) stabilise at particular points in time, then this must be conceived as the result of contingent hegemonic struggles, rather than immanent laws entailed in any one of these particular determinations.

Laclau's notion of globalised capitalism should perhaps first and foremost be conceived as a response to a particular reading of capitalism, namely one that seeks to explain it in purely economic terms. The argument provided by Laclau is, rather, that the economy cannot be seen as the base determining each of the other determinations in the last instance. As he makes clear, "[w]e can no longer understand capitalism as a purely economic reality" (Laclau 2005, 230). Instead, Laclau states that it "results from contingent hegemonic articulations" leaving "the relations between its component elements [...] essentially unstable and constantly displaced by historical contingent interventions" $(2000,292)$. This also means that there is "no last instance on the basis of which society can be reconstructed as a rational and intelligible structure" (Laclau and Mouffe 1990, 115, original emphasis), no unified ground instigating the social, no economy that acts as base.

This take on capitalism-in which it is given as a heterogeneous whole that manages to stabilise through contingent, hegemonic projects of power-does not exclude that any one of these particular determinations may play a crucial or uneven role. While globalised capitalism does decentre the economy as the transcendental motor governing history-the unifying ground from which all other relations can be deduced-it does not deny the importance of the economy. In a response to Slavoj Žižek, Laclau actually argues that: "The truth is that the economy is, like anything else in society, the locus of an overdetermination of social logics, and its centrality is the result of the obvious fact that the material reproduction of society has more repercussions for social processes than do other instances. This does not mean that capitalist reproduction can be reduced to a single, self-defining mechanism" (Laclau 2005, 237). According to Laclau, the economy has a centrality that "nobody seriously denies" (Laclau 2005, 237), yet this centrality is not an a priori ground from which the social can be founded. The centrality of the economy is, in other words, not a transcendental claim, but a historical one.

From the perspective of this particular paper, three overall questions should be further elaborated vis-à-vis Laclau's conception of capitalism: (1) What is the internal consistency of Laclau's notion of globalised capitalism? (2) What is the role of media within such a conception? And (3) how does this particular perspective on capitalism influence Laclau's wider theoretical project. Why does Laclau's approach "need" globalised capitalism?

First of all, the question of internal consistency. On this point, what is important to notice is the types of arguments used by Laclau when describing globalised capitalism. As argued above, he characterises this formation as a "new" stage, which can "no longer" be seen as purely economic, and so on. In this sense, everything about Laclau's argumentation amounts to what can basically be seen as historical arguments. These arguments are, in other words, a way of characterising the current stage of capitalism: They designate a particular historical form of capitalism. In this sense, these arguments are not meant to describe the constitution of capitalism across time and space. Yet, at the same time, Laclau formulates these arguments at a very high level of abstraction. Contra the appearance of his argumentation, it seems to me that Laclau does indeed not offer a fully-fledged diagnosis of this new stage of capitalism. Rather, he lays out a series of arguments or conditions that must be taken into account if such a diagnosis was to be made.

As Laclau and Mouffe $(2014,126)$ argue elsewhere, "[p]lurality is not the phenomenon to be explained, but the starting point of the analysis". A similar argument could be made in the context of Laclau's conception of capitalism: Heterogeneity is not the phenomenon to be explained, but the starting point of the analysis. Laclau is, in other words, claiming that if one wants to understand the current stage of capitalism, one would have to think of it as a heterogeneous set of autonomous determinations that have managed to create $a$ (or, indeed multiple) particular form(s) of hegemony. Instead of diagnosis, we are offered the pre-conditions 
for a diagnosis. And, at the same time, these pre-conditions are in and of themselves historical. In this sense, Laclau does not analyse the contents of capitalism as a hegemonising force, but diagnoses its form. If taken to its logical conclusion, then, globalised capitalism must basically designate a formalistic concept. If, however, this is the case, then how are we to understand the de-centring of the economy discussed above?

In this context, Slavoj Žižek (2000a, 2000b), for example, has pointed out that Laclau's notion of capitalism de-emphasises the specificity of capitalism as a particular kind of exploitative logic. In being described as contingent and heterogeneous, any potential underlying and unified logic governing capitalism across the different determinations is lost in Laclau's description. This argument is, in my view, a pretty consistent consequence of Laclau's position insofar as it denies the possibility of defining capitalism as a single, self-sufficient centre of power. Yet, unlike Žižek, the biggest problem with Laclau's notion is in my view not to be located within the context of his particular description of this form, but rather vis-à-vis his rationales for emphasising this particular form. As discussed above, globalised capitalism emerges at a particular point in time according to Laclau: it is a historical construct. If this is the case, and globalised capitalism actually is a particular historical form of capitalism, then how are we to interpret his emphasis on the economy as important for the reproduction of social life? As shown above, Laclau actually affirms the centrality of the economy as fundamental for the reproduction of society. This, surely, must also be an historical argument. But if this is the case, then why is the economy placed on the same field as these other determinations? It seems to me, to be quite clear, that there is an inconsistency to be found here: on the one hand, the economy is decentred on historical grounds, while, on the other, it is given a central position, also on historical grounds.

The problem here is not that Laclau wants to go beyond a model that is grounded in a classic base/superstructure model. In my view, the problem is rather that his reason for wanting to go beyond this model is given as a quasi-historical argument, while it is in fact a theoretical or even ontological argument concerning the constitutive lack perforating any and all discourses, the need for a constitutive outside, and the impossibility of grounding the social in any ultimate or self-sufficient foundation. To put it somewhat differently, I think Laclau gives us a basically theoretical argument concerning the form of capitalism disguised as a historical argument. What is more, even as an historical argument, it seems to be underdeveloped. What, for example, is the status of these determinations? Are they to be seen as discourses? Should they be considered as a kind of macro-discourses? And how can the limits of each of these particular determinations be observed? It seems peculiar that Laclau has to introduce reified theoretical totalities-technological, military and economic determinations -into a style of theorising that is otherwise dedicated to dispensing with such totalities (such as, most famously, the notion of 'society').

Second, how should media be conceived within this perspective on capitalism? To this effect, Laclau offers very few thoughts on the media as a specific site in which discourses are produced, transformed and sustained. Within the existing research on Laclau and media studies, however, some initial answers have been provided to this question. Phelan and Dahlberg (2011), for example, approach the relation between discourse theory and (what they term as) critical media politics as connecting by "a broad, open-ended conception of how the political and politics in contemporary societies are articulated through, and dependent on, the convenient shorthand that we call 'the media'" (Phelan and Dahlberg 2011, 5).

In a broader, yet still media-oriented context, this resonates with Carpentier and De Cleen's (2007) argument that within discourse theory, "media are seen not just as passively expressing or reflecting social phenomena, but as specific machineries that produce, reproduce and transform social phenomena" (274). Further unfolding this latter argument, these authors have suggested drawing on Torfing's (1999, 212-213) tripartite division in which discourses and media can be seen as interlinked in three distinct ways: as (1) discourses about the media (how media are articulated as occupying a particular role and function within society), (2) discourses produced by the media (the content produced by the media), and (3) media as discourses (media as discursive constructs in and of themselves). 
If this division is linked to the above discussion of globalised capitalism, these categories can be further unfolded. In the first instance (discourses about the media), the discourses must be understood as going across and between the different spheres of society. The question here, then, is how media are given meaning and articulated within and across different determinations. In the second instance (discourses produced by media), what is at stake is basically the discourses produced by the media. This may both be given as a mediation of other spheres-e.g. politicians or citizen groups using particular media to voice particular discourses-but it may also reflect the contents created by a medium in and of itself. In the third instance, media are seen as discursive constructs in and of themselves. This entails a perspective on the media as not only mediating content, but also as institutions embodying certain discourses and holding a particular place within the broader function of society. In this regard, the media starts coming into view as a particular determination with its own autonomy participating in the reproduction of globalised capitalism.

If this tripartite function of media is accepted, then it does seem valid to state that the media play a fundamental role in mediating across and between different systems in society, while also constituting a discrete determination in and of itself. An important question, in this regard, is how particular discourses about the media influence the ways in which particular media are constituted. That is to say, how certain ideas about what media should or should not be, constructed within e.g. the political system based on particular forms of justifications, manage to hegemonise the type of media that are allocated economic resources.

Finally, why does Laclau need the particular notion of globalised capitalism? In my view, it serves as an explanatory device used to ground his notion of populism and political struggle. If, for a moment, Laclau's formal description of globalised capitalism as discussed above is accepted, then it simultaneously becomes clear that a critique of the existing order cannot simply be a critique of the economy. Contrary to classic Marxism-which views the simplification of the social space into two antagonised camps as an inevitable feature of the internal dynamics of the economic system - a necessarily heterogeneous form of capitalism cannot produce such a priori points of antagonism. Laclau $(2005,150)$ writes that "there are no a priori privileged points of rupture and contestation" and that "there is no reason why struggle taking place within relations of production should be the privileged points of a global anticapitalist struggle" (ibid.).

This also means that classes and class relations cannot be given a privileged role. If capitalism does not lead necessarily to a situation in which one class is put directly against another, then one cannot expect struggle to emerge necessarily from class relations. Thus, because the economy is no longer the underlying ground instituting the social, a critique of the economy does not automatically lead to the transformation of society in its entirety. In this sense, political struggle must rather seek to unite a plethora of particular struggles - within and across each of the particular autonomous determinations-in a common struggle. It is at this point that we find Laclau's (2005) theory of populism.

To distil the argument made by Laclau (2005) to its bare essentials, populism cannot be deduced or seen as the product of any underlying essential conditions. Instead, political struggle must be located within the field of political demands articulated by contingent actors within certain historical conditions. If this is the case, then it also means that the impossibility of determining the grounds of society also leads to an impossibility of determining social struggles and their emergence. The challenge, then, to any populist movement-the construction of a 'people'-is how to unite a multiplicity of different demands, across different sectors of social life, under a common signifying practice (the production of an empty signifier), a 'common language' $(2005,231)$. It is only through a heterogeneous struggle that a heterogeneous system can be transformed. Once again, heterogeneity is not the phenomenon to be explained, but the pre-conditions for the analysis.

The important point here is that this inability to deduce the points of emergence of struggle goes hand-in-hand with Laclau's diagnosis of the current political regime as a form of globalised capitalism. It is because "globalized capitalism creates myriad points of rupture and antagonism-ecological crisis, imbalance between different sectors of the economy, massive unemployment, and so on-and only an overdetemination of this antagonistic plurality can 
create global anti-capitalist subjects capable of carrying out a struggle worth the name" (Laclau 2005, 150). In the end, Laclau offers a double argument that links the current form of capitalism with the form of social and political struggle. This double argument is already present towards the end of Hegemony and Socialist Strategy. Summarising the main arguments of this book, Laclau and Mouffe (2014 [1985], 176) write: "Every project for radical democracy necessarily includes, as we have said, the socialist dimension-that is to say, the abolition of capitalist relations of production; but it rejects the idea that from this abolition there necessarily follows the elimination of the other inequalities". What is important to notice here is how Laclau's wider theoretical categories rest on his particular analysis of the capitalist system. This also means that in employing these theoretical categories for analytical or empirical purposes, there is a tacit acceptance of this particular analysis. It seems to me that the consequences of this double argumentation are rarely reflected upon.

\subsection{What about Class and Political Economy in Laclau's Work?}

One of the standard objections to Laclau's work, and, indeed, post-Marxism as such, is that it leaves little to no room for neither the economy nor class relations (see Howarth 2000, 111115). As described above, this objection is reasonable insofar as Laclau does, however inconsistently, de-emphasise the economy as the material ground of society. Yet, as I will discuss in this section, this does not necessarily lead to a complete disregard of neither the economy nor class relations.

Most of Laclau's objections to economic reductionism can more or less be transferred directly to his arguments concerning class and class relations. Laclau's main argument in this respect is not (and this should be stressed) that there is no such thing as classes or class relations. Such an argument would be absurd. Rather, in an analogues fashion to his characterisation of the economy, Laclau argues that class relations should be seen on the same terrain as a number of other differences (sexual, cultural, ethnic, and so on). Thus, in the same way that Laclau approaches the economy as one amongst other "determinations", class relations are also placed on the same level as other differences in the field of particularistic social struggles: Classes are one area in which struggles may emerge, but certainly not the only one. And just as Laclau does not see the economy as the historical engine from which all other social phenomenon can be deduced, he also de-emphasises classes as the primary terrain causing social struggle.

What is at stake in this argument can be further unfolded by reference to Žižek's critique of Laclau. Žižek (2000b, 320, original emphasis) argues that his "point of contention with Laclau [...] is that I do not accept that all elements which enter into hegemonic struggle are in principle equal: in the series of struggles (economic, political, feminist, ecological, ethnic, etc.) there is always one which, while it is part of the chain, secretly overdetermines its very horizon". The one particular struggle overdetermining the others is, for Žižek, class struggle. Laclau $(2005,237-239)$ has responded specifically to this objection by stating that, up to a certain point, he agrees with Žižek in that social reality is never merely an undifferentiated or even horizon. However, according to Laclau, the unevenness of the social is precisely the outcome of hegemonic struggles. Rather than using class as an explanatory model, it is class relations-and their stabilisation within particular hegemonic projects-that should be explained. The question here is essentially, as Laclau $(2005,236)$ emphasises, a difference in terms of viewing class relations as transcendental, the secret particularism that necessarily determines all other particularisms, or as historical, the outcome of contingent hegemonic struggles that may or may not, at particular points in time, exert an influence on the social in various ways.

Laclau's arguments should be considered carefully insofar as they point to the fundamentally pluralistic and heterogeneous composition of social reality. Yet, at the same time, they may also be problematised along two fronts. First of all, we should be careful not to view this perspective on class as (an implicit) legitimisation of the hegemonic neo-liberal order, which attempts to cover up exploitive class relations. Laclau's decentring of class should not, in my view, be read as a neutralisation of class relations. On the contrary, discourse theory should 
take a critical stance on any such attempt to neutralise or essentialise exploitive relations perpetuated by e.g. neoliberal media. Second, contrary to Laclau, I think the question of class and class relations remains much more open than what he sometimes makes it seem, both historically and theoretically (see e.g. Skeggs 2004; Wright 2015). Even if classes cannot be seen as the primary historical motor of social change, this does not necessarily mean that they do not play a constitutive role in shaping how particular discourses are constructed. Wood and Skeggs' (2011) edited volume on reality television and class is one, among many, reminders of this: Class still matters if we want to understand the media. Not only in relation to how particular classes are constructed in the discourses articulated by different media, but also in terms of the exploitation of labour entailed in the reproduction of particular media institutions, corporations, or devices.

This leads to a second, widespread critique of discourse theory, which claims that it leaves little to no room for critical political economy. This has been discussed by a number of authors recently, who have attempted to combine political economy, critical media studies, and discourse theory (see Mylonas 2014; Dahlberg 2011, 2014; Phelan and Dahlberg 2011, 2014; Best 2014). The typical critique of post-Marxism is that it discards political economy and renders any systematic engagement with the structural mechanisms embedded within capitalism impossible (Žižek 2000a, 2000b; Geras 1987). While part of this critique may stem from Laclau's opposition to the classic Marxist conception of base and superstructure (as discussed above), what really seems to be at stake is actually an ontological question concerning the ways in which discourse theory conceives materiality and materialism vis-à-vis how classic Marxism views these phenomena (as has been discussed by e.g. Mylonas 2014).

To put it somewhat oversimplified, discourse theory rejects any distinction between the discursive and the non-discursive (Laclau and Mouffe 2014 [1985], 93-94; Laclau and Mouffe 1990 [1987], 100-101; Laclau 2005, 68). It rejects, in other words, the notion that only particular parts of social reality are discursive (e.g. language), while others are outside of discourses (institutions, practices, and objects). All objects, insofar as they are constituted as meaningful objects, are objects of discourse and there is no external site outside the discursive from which they can be given meaning: "Discourse is the primary terrain of the constitution of objectivity as such. By discourse, as I have attempted to make clear several times, I do not mean something that is essentially restricted to the areas of speech and writing, but any complex of elements in which relations play the constitutive role" (Laclau 2005, 68, original emphasis).

The argument here should not be read as a kind of idealism, in which social reality is reduced to mental representations. Discourses are not to be conceived of as linguistic or mental constructs, as they always have a material character, being embedded within particular institutions, making use of and organising certain objects, and so on (Laclau and Mouffe, 2014). Nor does discourse theory engage in a kind of anti-realism arguing that there is no world external to the mind or meaning. Objects do exist outside of discourses, Laclau and Mouffe (2014) maintain, yet insofar as these objects are constituted as meaningful objectsby being positioned within a particular system of signification-they necessarily become objects of discourse: "The fact that every object is constituted as an object of discourse has nothing to do with whether there is a world external to thought, or with the idealism/realism opposition" (Laclau and Mouffe 2014, 94, original emphasis).

If this is the case-and all discourses are necessarily material-then this also means that the economy does not constitute a "special" discourse. As Dahlberg $(2011,54)$ rightly argues, the economy is just as discursive and just as material as anything else that is discursive: the economy does not provide the material ground from which all other parts of society are maintained or can be grounded. Not only does this break with the materialism advocated by traditional views of base and superstructure, but it also makes problematic any analytical framework that seeks to understand the economic system as a set of structural mechanisms given outside of discourses. It is against this backdrop that political economists tend to be sceptical about discourse theory, asking where does this theory leave political economy? 
In the context of media studies, besides the suggestion to outright discard post-Marxism, current research has adapted two parallel solutions to the question of discourse theory and political economy. The first solution, mainly advocated by Lincoln Dahlberg $(2011,2014)$, consists in using discourse theory to engage in what he terms a radical political economy. Dahlberg suggests a form of political economy that takes (radical) contingency as its point of departure and asks how the economy-understood as the "sphere of life associated with the hegemonic institutionalization [...] of discursive systems associated with what is understood to be the material production and re-production of life" (54-55, original emphasis) - has come to constitute and neutralise itself as a discursive system.

According to Dahlberg (2011), radical political economy seeks to bring forth the ways in which economic structures are used to legitimise the hegemonisation of particular media instead of others. Exemplifying this position, Dahlberg argues that such forms of political economy could scrutinise the "legitimation and institutionalization of private media systems in contrast to public service media, or community media" (56). What is at stake here, then, is the discursive construction of the economy understood as a particular system of meaning. The aim is not to engage in critical political economy as it is understood within classic Marxism, but rather to supplement this analysis with an investigation that seeks to understand how economic justifications and rationales are used to express the function of the economy and legitimise capitalist or neo-liberal discourses and media. In this context, Dahlberg (2014, 268) makes clear that this should not be seen as an abandonment of critical political economy, but rather a "supplement to other critical political economy critiques of capitalism".

The strength of Dahlberg's approach is that it manages, very carefully, not to go beyond the boundaries of Laclau's ontological arguments. However, this particular integration of political economy within discourse theory provides less of an answer to how traditional political economy and discourse theory can be thought in relation to one another, and more a particular form of discourse theory emphasising economic discourses. Radical political economy, in this sense, becomes a particular subset of discourse theory, a form of discourse theory that is focused on economic justifications and rationales.

A second path, shown by e.g. Yiannis Mylonas (2014, see also Best 2014), proposes to use discourse theory in parallel with the more established form of critical political economy. The main argument here is that there are, in fact, certain structural mechanisms that cannot be adequately explained within the boundaries of discourse theory. Rather than wanting to purely diagnose the economic system and its consequences in terms of (the social construction of) meaning, Mylonas $(2014,319)$ advocates a complementary approach, in which political economy provides a parallel toolbox. Thus, he argues:

Capitalism reaches crises due to 'objective' conditions (which have a discursive foundation), relating to the fall of expected rates of profit, the changes in the composition of fixed and variable capital for the maximization of productivity, or to emerging contradictions related to catastrophes capitalism produces, and also due to subjective reasons, related to antagonism between rival capitalists and social classes. Discourse is central in all these features, objective and subjective ones, but a strictly discursive approach to the analysis of capitalist crises would be reductionist. A synthesis of critical and post-structuralist traditions of research can broaden the understanding of the crisis' complexity (Mylonas 2014, 319).

In this approach, rather than an attempt to economise discourse theory, Mylonas advocates a 'synthesis' of different fields: He argues that discourse theory and critical political economy can offer complementary analytical strategies. In my view, the main advantage of this approach is that it allows us to take advantage of both the analytical categories provided by discourse theory and is able to analyse economic structures using Marxist concepts: Media both constitute particular discourses and are given as material economic structures, which are irreducible to discursivity.

The main drawback here is that all of the potential problems avoided by Dahlberg-the intermeshing of incompatible ontologies-cannot be completely evaded. The question still re- 
mains, in other words, how to conceive of the materiality of the economy within Laclau's ontology.

These two paths - the economisation of discourse theory and the parallel integration of critical political economy and discourse theory-are not mutually exclusive, and in a certain sense the latter approach might even represent the kind of supplement advocated by the first. What they both share, however, is the premise that discourse theory is not (in any way) opposed to critical political economy and that it may, on the contrary, provide a solid supplement to this trajectory. As Dahlberg (2011, 56, original emphasis) rightly emphasises, "discourse theory provides a contribution to critical political economy, rather than being an enemy of such". This also means that despite Laclau's (partial) dismissal of the economy and class, discourse theory can indeed still provide insights that are helpful for political economy. If the construction of particular mediated discourses-whether about, through, or within media-are to be fully understood, the integration of critical political economy and discourse theory provides an exciting and necessary way forward.

\section{Critique: Back to the Hegemonic Struggle}

Up to this point, this paper has emphasised how Marxism plays a crucial role in framing Laclau's work and his reflections on its intellectual trajectory. The paper has furthermore discussed and problematised Laclau's notion of globalised capitalism with a focus on its consequences for critical political economy and its wider influence on his theoretical work. Through this discussion, both potentials and inconsistencies facing a systematic engagement with and against capitalism within media studies have been highlighted. Section 4 turns towards the question of critique: How and in what way can discourse theory be operationalised as a critical approach in the context of media studies? And what are the conditions for utilising discourse theory? The basic argument developed in section will be to push Laclauian discourse theory further in the direction of a normative political agenda. Against accusations of relativism, the section will attempt to highlight a more nuanced perspective on Laclau's work.

One of the most productive ways of articulating the critical potentials of discourse theory, within the context of critical media studies, has been to frame it as a form of ideology critique (see e.g. Dahlberg 2011; Phelan 2016). It should be immediately noted that Laclau does not refer to the classic Marxist notion of ideology, understood as a form of false consciousness that "masks real economic relations of exploitation" (Phelan and Dahlberg 2011, 26; see Laclau 1990, 89-92). Such an understanding of ideology is fundamentally incompatible with Laclau's ontological framework. According to Laclau, the problem with this particular way of conceptualizing idelogy is not only that it rests on an essentialist conception of the social, but also that it is rooted in a distinction between a true-false identity in which the "true identity" implies a "positive and non-contradictory" ground (Laclau 1990, 91). Seen from the side of Laclauian discourse theory, which sees the social as always perforated by a constitutive lack and a radical negativity that posits the identity of any given agent as given in the antagonised relation to a threatening other, this position cannot be maintained. There simply cannot be a "positive" and self-sufficient identity.

To avoid these incompatibilities, Laclau $(1990,92)$ actively reconstructs the notion of ideology to designate "those discursive forms through which a society tries to constitute itself as such on the basis of closure, of the fixation of meaning, of the non-recognition of the infinite play of differences". Ideology, according to Laclau, implies a form of misrecognition, in which a particular discourse is perceived as positive, neutral or self-sufficient. It consists, in other words, in viewing a particular system as simply given, as something that cannot be otherwise; "a desire for total closure by political projects" (Howarth 2000, 122, original emphasis). As Phelan and Dahlberg $(2011,27)$ neatly put it, ideology "is present when a particular discursive system, such as neoliberalism, is seen as 'all there is', its hegemonic logics having become so naturalised and sedimented that the political [...] conditions of its initial discursive constitution are no longer socially recognized".

Ideology critique, then, consists in de-neutralising or de-essentialising that which appears as neutral. It is, as an opt-quoted passage by Laclau $(1990,92)$ reads, a "critique of the "nat- 
uralization of meaning' and of the 'essentialization of the social'". Ideology critique, in this sense, is close to what Laclau, appropriating a set of concept from Husserl, terms reactivation. In opposition to sedimented discourses, which are structures that have managed to neutralise themselves through a "routinization and forgetting of origins" (Laclau 1990, 34), reactivation designates a retrieval or re-sensitisation towards the necessary contingency of any such discourse. Thus, "[r]eactivation does not [...] consist of returning to the original situation, but merely of rediscovering, through the emergence of new antagonisms, the contingent nature of so-called 'objectivity'. In turn, however, this rediscovery can reactivate the historical understanding of the original act of institution insofar as stagnant forms that were simply considered as objectivity and taken for granted are now revealed as contingent and project that contingency to the 'origins' themselves" (Laclau 1990, 34, original emphasis).

Reactivation is, in other words, a re-politicisation of the contingency of the social: It is a way of de-objectifying (so-called) objectivity by bringing the always-necessarily exclusionary dimension back into view. It consists in bringing back the "original meaning of the social", Laclau writes elsewhere, by "showing its political essence" $(1990,160)$. Here, however, essence is not to be conceived as a particular a priori or transcendental content, but rather as a certain form through which social reality is instituted. In this sense, showing the political essence designates an uncovering of the "moment of original institution of the social [that] is the point at which its contingency is revealed" (Laclau 1990, 34, original emphasis), which also showcases "the original violence, of the power relations through which that instituting act took place" (ibid.).

Laclau's re-constructed notion of ideology is not necessarily something that can or should be totally eradicated. Ideology is rather something that is integral to everyday life, and, as such, cannot be avoided. In this sense, the aim of ideology critique is "both [to] illuminate the political and social conditions that enable a particular ideological regime to sustain itself and to productively imagine how different (and better) forms of ideological attachment and identification might be made possible" (Phelan 2016, 282, original emphasis).

If conceived in this way, Laclau's conception of ideology begins to approach part of the critical terrain more familiar to classic Marxism. As has been discussed by e.g. Devenney (2004), this form of critique (and, indeed, Laclau's wider political project) can be read as a critique of the instrumentalisation of knowledge, language, and the subject. Ideology critique can be seen as coming close to a critique of the fetishisation and neutralisation of social structures. To stretch the argument even further, Laclau's ideology critique even resembles, though he would perhaps object to this comparison, part of the logic found in Lukács' notion of reification. It is a way of showing how that which appears as simply given is in fact the outcome of particular historical systems and political decisions.

Connecting this discussion to the earlier tripartite division of media and discourses, ideology can seen as working on three distinct levels in the context of the media: as ideological discourses about the media, i.e. discourses that position certain media as neutral, necessary or essential to the function of society; as ideological discourses distributed through the media, i.e. discourses that are articulated through the media claiming to be neutral or ahistorical; or as media taking on the appearance of neutral constructs in and of themselves. Coupling this with the radical political economic perspective discussed above (Dahlberg, 2011), it would furthermore be possible to show how such ideological claims have worked in conjunction with economic rationales and justifications concerning the supposed necessity of certain economic structures. It would, in other words, be possible to show how certain capitalist me-

\footnotetext{
${ }^{5}$ As Beverly Best $(2000,47)$ notes in a footnote: "It does not seem to me that Laclau's use of the concept of sedimentation is much different, if at all, from the Marxist use of the concepts 'reification' or 'fetishization'". Though I agree with Best in that there are strong affinities between Laclau's notion of sedimentation and more traditionally Marxist notions of reification, some important ontological distinctions should be made, namely Laclau's insistence on a fundamental lack inherent to all discourses, the impossibility of grounding the social in any ultimate foundation, and the inability to deduce processes of reification or fetishisation (sedimentation) from purely economic explanatory models. Thus, while the conceptual pair sedimentation-reactivation does resemble part of the logic found within Lukács' (1971) notion of reification, it does not rest on the same ontological arguments. In this context, Laclau particularly objects to the ways in which reification and false consciousness are linked within the work of Lukács (see Laclau 1979, 63, 125, 159; 1990, 68, 114; 1996, 80; 2014, 143-144, 157).
} 
dia have attempted to neutralise themselves through economic justification or how particular discourses about the media-e.g. the relation between public service and capitalist media, or the relation between a commons-based Internet and one run by multinational media conglomerates-have attempted to essentialise themselves.

What are the conditions for conducting this type of ideology critique? In this context, Dahlberg $(2011,44)$ has argued that the primary condition for this form of critique is to accept (radical) contingency as a necessity: "it is clear that a minimum implication of discourse theory for critique is a commitment to openness or radical contingency" $(2011,44$, original emphasis). While I agree that a commitment to contingency is one particular condition, further criteria should be added based on Laclau's work. At the very least, as far as I read Laclau, three additional arguments should be made:

(i) While post-Marxism does entail the need for a continuous and self-reflexive scrutiny, this does not necessitate the abolishing of any and all emancipatory projects: on the contrary. Thus, while Laclau $(1990,188)$ makes clear that it is necessary to engage systematically in "a critique of the fundamentalism of the emancipatory projects of modernity", he also states that this "does not involve an abandonment of the human or political values of the Enlightenment, but a different modulation of its themes". The argument here is that while any project for the constitution of society cannot be grounded in an ultimate and fixed essence, this does not mean forfeiting any and all emancipatory projects. Rather, "[t]hose that for modernity were absolute essences have now become contingent and pragmatic constructions" (Laclau 1990, 188-189). As pragmatic constructs, political visions should not necessarily be left out, but located within concrete hegemonic struggles. In this sense, "the abandonment of the myth of foundationalism does not lead to nihilism [...] [but] further radicalizes the emancipatory possibilities offered by the Enlightenment and Marxism" (Laclau, in: Marchart 2007, 156). The deconstruction of tradition should not merely lead to an absence in the form of a "collapse of all radical tradition" (Laclau 1990, 193, original emphasis).

(ii) Laclau $(1990,190)$ emphasises that political visions cannot be deduced from neither post-structuralism nor post-Marxism as theoretical systems: "the currents that have been called post-structuralist have created [...] a certain intellectual climate, a certain horizon that makes possible an ensemble of theoretico-discursive operations". This climate has allowed for a theoretical reformulation of Marxism beyond any stable and essential ground. Yet, by opening such theoretical perspective, it has simultaneously allowed for the "deepening of those political practices that go in the direction of a 'radical democracy'" (Laclau 1990, 190). At this point, Laclau makes clear that theory cannot be equated with the production of a certain normative order, though it may help advance any such order through concrete practices. While this argument may appear minor, it also means that-contra e.g. Rancière's (1999) conception of politics or Hardt and Negri's (2004) notion of the multitude and "beingagainst"- - political project for the Left cannot be directly inferred or deduced from discourse theory. There is no reason why political struggle, as it is conceived by Laclau, must be political struggle for Left or progressive politics. Emancipation, equality, and justice are not necessarily embedded within his theoretical categories.

This also means that while Laclau does open (and, even, emphasise) the need to conjure up new radical and normative projects, discourse theory cannot provide resolute and a priori answers to ethical questions. It is, in other words, simply not possible to deduce a transhistorical politics or ethics from discourse theory as an intellectual framework. The answer, then, to particular ethical questions-why $X$ or $Y$ is bad, evil or destructive-must rather be seen in their entire radical contingency, as acts of genuine decisions. Such acts of decision have an imminently practical aspect. They will always be situated within a terrain of competing discourses, competing attempts to hegemonise the social: "if the decision is one between structural undecidables, taking a decision can only mean repressing possible alternatives that are not carried out. In other words, that the 'objectivity' arising from a decision is formed, in its most fundamental sense, as a power relationship" (Laclau 1990, 30).

As Laclau maintains, the contingency of the decision should not lead to pessimism: "if social relations are contingent, it means they can be radically transformed through struggle, instead of that transformation being conceived as a self-transformation of an objective na- 
ture" (Laclau 1990, 35-36, see also Laclau 2001, 14). This line of argumentation sometimes leads to a critique of Laclau (and Mouffe) for being relativist, as the foundation for making truth claims is made contingent and historical rather than essential. However, as Howarth $(2000,123)$ has forcefully argued, this type of "enlightenment blackmail", in which "unless one has or invokes absolute foundations to defend a political project, then one has no ground whatsoever", should not be accepted. Instead, any political project will have to compete against other historical hegemonic projects, and it is therefore "the actual proposals they [Laclau and Mouffe] (and others) put forward which must be evaluated and not the conditions of possibility for making any judgement at all" (Howarth 2000, 123).

(iii) Laclau has stated that the role of the intellectual should be recast following the Gramscian notion of "organic intellectuals" (Laclau 1990, 195-196; Gramsci 2005 [1971]). Thus, according to Laclau $(1990,196)$, intellectuals should contribute by inventing languages, without, however, taking the role of an authoritarian elite, instead emphasising the ultimately collective aspect of social change.

These three conditions go beyond merely accepting contingency: They require a political practice. With these added conditions in mind, it is feasible to construct a version of discourse theory that goes beyond merely de-essentialising, de-neutralising and critiquing essences. It is, rather, a discourse theory that does not push normativity to the side, but locates it as a vital part of any critical project. As Laclau $(1990,193)$ emphasises, the deconstruction of social reality "paves the way for a retrieval of the radical tradition, including Marxism" $(1990,193)$. Thus, "[o]ne also needs to know for what one is fighting, what kind of society one wants to establish. This requires from the Left an adequate grasp of the nature of power relations, and the dynamics of politics. What is at stake is the building of a new hegemony. So our motto is: "Back to the hegemonic struggle"' (Laclau and Mouffe 2014 [1985], xviii-xix).

If we accept this imminently practical slogan-back to the hegemonic struggle-then research cannot simply critique the closure of meaning. Research must, rather, engage in a systematic and normative critique of subordination and oppression, which explicitly and openly attempts to forge new political projects that revitalise the radical tradition. Back to the hegemonic struggle is imminently a call for political practice through research that takes normative questions seriously.

\section{Conclusion: The Implications of Ernest Laclau's Approach for Critical Media Studies}

In this paper, I have covered considerable ground, spanning multiple questions and discussions. Yet, these different intersecting readings have all been fuelled by the same underlying aim, namely to emphasise the fruitfulness of engaging, both affirmatively and critically, with Laclau's work in the context of critical media studies. If one refers to compressed versions of discourse theory, limited to a few selected concepts, one risks reducing Laclau's arguments by decontextualising them from their originally intended context. This paper has, in an opposite way, tried to highlight how engaging with Laclau's work can be productive. While this effort should certainly not be seen as exhaustive, it may provide a constructive starting point for further discussions. In this final section, I will briefly explicate three main implications for critical media studies based on the arguments presented in this paper.

First, I showed how Marxism and the Marxist tradition play a crucial role for Laclau (section 2). Rather than being limited to a marginal position or a purely negative point of criticism, it is my contention that Marxism-understood as a heterogeneous intellectual tradition privileging emancipation and the systematic critique of exploitation, alienation and subordination-constitutes the primary historical backdrop to discourse theory. Critical media research should take this Marxist dimension into account when approaching and utilising Laclau's work. This does not only entail a certain normative-critical position, but also provides an opportunity to think across and develop constructive dialogues with other forms of Marxist critical media studies. In this sense, discourse theory is open to engaging with and appropriating core concepts from other strands of research, as long as the basic ontological arguments are kept intact (see also Torfing 1999, 290-292). 
Second, I argued that Laclau's theoretical perspective on political struggle (populism) was bound up with a particular take on (globalised) capitalism and class relations (section 3). By critically discussing this relation from several perspectives, I attempted to show some of the problems and ambiguities contained within these notions. One potential road for future research could be to begin incorporating, in a more direct manner, class analysis and political economy in conjunction with discourse theory. As I have discussed in this paper, the emergent literature on the connection between discourse theory and political economy shows great promise in this area (Dahlberg 2011, 2014; Mylonas 2014). Research along these lines may begin to deconstruct the ways in which class relations influence the production of discourses or how particular forms of labour have been justified by drawing on economic justifications and rationales.

Finally, I discussed the question of discourse theory and ideology critique (section 4), a theme that has been re-actualised by a number of critical media scholars (Phelan 2016; Phelan and Dahlberg 2011; Dahlberg 2011). My main argument here was that ideology critique is not just a critique of the essentialisation, neutralisation, and routinisation of the social, but that it must be conceived within the context of an emancipatory rethinking of the social. It seems to me that this argument pushes Laclau further than what is usually attempted within the context of critical media studies. What is at stake, in my view, is not just an embedded form of normativity within the theory itself (Critchley 2004; Marchart 2004), but an intentional political sensibility. According to Laclau (1990, 1996), any emancipatory project can never be based on an ultimate foundation or ground. Rather, it will have to remain a contingent and pragmatic construct perforated by a constitutive lack that should be continuously and selfreflexively scrutinised. Yet, keeping this in mind, I still maintain that the formulation of such projects is an integral part of Laclau's political and theoretical work. Pushing this point even further, returning in an almost cyclical manner to the first of the three arguments presented, this emancipatory project should be located within a socialist/Marxist trajectory, as a revitalisation of a historical and radical tradition. If conceived in this light, discourse theory may begin to come into view as a genuinely critical theory that is simultaneously explanatory, practical and normative. In an era dominated by capitalist media and neoliberal hegemony, such critical theories are urgently needed.

\section{References}

Andersen, Niels Åkerstrøm. 2003. Discursive Analytical Strategies: Understanding Foucault, Kosselleck, Laclau, Luhmann. Bristol: Policy Press.

Askanius, Tina and Yiannis Mylonas. 2015. Extreme-Right Responses to the European Economic Crisis in Denmark and Sweden: The Discursive Construction of Scapegoats and Lodestars. Javnost - The Public: Journal of the European Institute for Communication and Culture 22 (1): 5572.

Askanius, Tina and Julie Uldam. 2011. Online Social Media for Radical Politics: Climate Change Activism on YouTube. International Journal of Electronic Governance 4 (1-2): 69-84.

Best, Beverley. 1999. Strangers in the Night: The Unlikely Conjunction of Fredric Jameson and Ernesto Laclau. Rethinking Marxism 11 (3): 1-19.

Best, Beverley. 2000. Necessarily Contingent, Equally Different, and Relatively Universal: The Antinomies of Ernesto Laclau's Social Logic of Hegemony. Rethinking Marxism 12 (3): 38-57.

Best, Beverley. 2014. Speculating Without Hedging: What Marxian Political Economy Can Offer Laclauian Discourse Theory. Critical Discourse Studies 11 (3): 272-287.

Bowman, P. 2007. Post-Marxism Versus Cultural Studies: Theory, Politics and Intervention. Edinburgh: Edinburgh University Press.

Carpentier, Nico. 2005. Identity, Contingency and Rigidity: The (Counter-)Hegemonic Constructions of the Identity of the Media Professional. Journalism 6 (2): 199-219.

Carpentier, Nico. 2010. Deploying Discourse Theory. An Introduction to Discourse Theory and Discourse Theoretical Analysis. In Media and Communication Studies Interventions, edited by Nico Carpentier et al., 251-266. Tartu: Tartu University Press.

Carpentier, Nico and Benjamin De Cleen. 2007. Bringing Discourse Theory into Media Studies: The Applicability of Discourse Theoretical Analysis (DTA) for the Study of Media Practises and Discourses. Journal of Language and Politics 6 (2): 265-293. 
Carpentier, Nico and Erik Spinoy, eds. 2008. Discourse Theory and Cultural Analysis: Media, Arts and Literature. Cresskill: Hampton Press.

Critchley, Simon. 2004. Is there a Normative Deficit in the Theory of Hegemony? In Laclau: A Critical Reader, edited by Oliver Marchart and Simon Critchley, 113-122. London: Routledge.

Dahlberg, Lincoln. 2011. Discourse Theory as Critical Media Politics? Five Questions. In Discourse Theory and Critical Media Politics, edited by Lincoln Dahlberg and Sean Phelan, 41-63. Basingstoke: Palgrave Macmillan.

Dahlberg, Lincoln. 2014. Capitalism as a Discursive System? Critical Discourse Studies 13 (3): 257271.

Dahlberg, Lincoln and Sean Phelan, eds. 2011. Discourse Theory and Critical Media Politics. Basingstoke: Palgrave Macmillan.

Dahlgren, Peter. 2011. Mobilizing Discourse Theory for Critical Media Politics: Obstacles and Potentials. In Discourse Theory and Critical Media Politics, edited by Lincoln Dahlberg and Sean Phelan, 222-249. Basingstoke: Palgrave Macmillan.

Dahlgren, Peter. 2013. The Political Web: Media, Participation and Alternative Democracy. Basingstoke: Palgrave Macmillan.

De Cleen, Benjamin. 2015. "Flemish Friends, Let us Separate!": The Discursive Struggle for Flemish Nationalist Civil Society in the Media. Javnost-The Public: Journal of the European Institute for Communication and Culture 22 (1): 37-54.

Devenney, Mark. 2004. Ethics and Politics in Discourse Theory. In Laclau: A Critical Reader, edited by Oliver Marchart and Simon Critchley, 123-139. London: Routledge.

Fenton, Natalie. 2011. Multiplicity, Autonomy, New Media, and the Networked Politics of New Social Movements. In Discourse Theory and Critical Media Politics, edited by Lincoln Dahlberg and Sean Phelan, 178-200. Basingstoke: Palgrave Macmillan.

Fenton, Natalie. 2016. Left out? Digital Media, Radical Politics and Social Change. Information, Communication \& Society 19 (3): 346-361.

Foucault, Michel. 1991 [1975]. Discipline and Punish: The Birth of the Prison. London: Penguin Books.

Fuchs, Christian. 2008. Internet and Society: Social Theory in the Information Age. New York: Routledge.

Fuchs, Christian. 2011. Foundations of Critical Media and Information Studies. New York: Routledge.

Geras, Norman. 1987. Post-Marxism? New Left Review 163: 40-82.

Gramsci, Antonio. 2005 [1971]. Selections from the Prison Notebooks of Antonio Gramsci. London: Lawrence \& Wishart Limited.

Hansen, Allan Dreyer and André Sonnichsen. 2014. Discourse, the Political and the Ontological Dimension: An interview with Ernesto Laclau. Distinktion: Scandinavian Journal of Social Theory 15 (3): 255-262.

Hardt, Michael and Antonio Negri. 2004. Multitude: War and Democracy in the Age of Empire. New York: Penguin Press.

Horkheimer, Max. 2002. Critical Theory: Selected Essays. New York: Continuum.

Howarth, David. 2000. Discourse. Buckingham: Open University Press.

Howarth, David and Yannis Stavrakakis. 2000. Introducing Discourse Theory and Political Analysis. In Discourse Theory and Political Analysis: Identities, Hegemonies and Social Change, edited by David Howarth, Aletta J. Norval and Yannis Stavrakakis, 1-23. Manchester: Manchester University Press.

Husted, Emil. 2015. From Creation to Amplification: Occupy Wall Street's Transition into an Online Populist Movement. In Civic Engagement and Social Media: Political Participation Beyond Protest, edited by Julie Uldam and Anne Vestergaard, 153-173. Basingstoke: Palgrave Macmillan.

Jørgensen, Marianne and Louise Phillips. 2002. Discourse Analysis as Theory and Method. London: Sage.

Kompatsiaris, Panos and Yiannis Mylonas. 2015. The Rise of Nazism and the Web: Social Media as Platforms of Racist Discourses in the Context of the Greek Economic Crisis. In Social Media, Politics and the State: Protests, Revolutions, Riots, Crime and Policing in the Age of Facebook, Twitter and YouTube, edited by Daniel Trottier and Christian Fuchs, 109-148. London: Routledge.

Kumpu, Ville. 2016. On Making a Big Deal. Consensus and Disagreement in the Newspaper Coverage of UN Climate Summits. Critical Discourse Studies 13 (2): 143-157.

Mouffe, Chantal. 2005. The Democratic Paradox. London: Verso.

Mouffe, Chantal. 2013. Agonistics: Thinking the World Politically. London: Verso.

Mylonas, Yiannis. 2012. Reinventing Political Subjectivities: Studying Critical Documentaries on the War on Terror. Social Semiotics 22 (4): 353-374. 
Mylonas, Yiannis. 2014. Crisis, Austerity and Opposition. In Mainstream Media Discourses Of Greece. Critical Discourse Studies 11 (3): 305-321.

Phelan, Sean. 2009a. Irish Neoliberalism, Media and the Politics of Discourse. In Transforming Ireland: Challenges, Critique, Resources, edited by Debbie Ging, Michael Cronin and Peadar Kirby, 73-88. Manchester: Manchester University Press.

Phelan, Sean. 2009b. The Newspaper as Political Antagonist: Editorial Discourse and the Othering of Maori Perspectives on the Foreshore and Seabed Conflict. Journalism 10 (2): 217-237.

Phelan, Sean. 2016. Reinvigorating Ideology Critique: Between Trust and Suspicion. Media, Culture \& Society 38(2): 274-283.

Phelan, Sean and Lincoln Dahlberg. 2011. Discourse Theory and Critical Media Politics: An Introduction. In Discourse Theory and Critical Media Politics, edited by Lincoln Dahlberg and Sean Phelan, 1-40. Basingstoke: Palgrave Macmillan.

Phelan, Sean and Lincoln Dahlberg. 2014. Introduction: Post-Marxist discourse theory and critical political economy. Critical Discourse Studies 11 (3): 255-256.

Laclau, Ernesto. 1979 [1977]. Politics and Ideology in Marxist Theory. London: Verso.

Laclau, Ernesto. 1990. New Reflections on the Revolution of Our Times. London: Verso.

Laclau, Ernesto. 1996. Emancipation(s). London: Verso.

Laclau, Ernesto. 2000. Constructing Universality. In Contingency, Hegemony, Universality: Contemporary Dialogues on the Left, Judith Butler, Ernesto Laclau, and Slavoj Žižek, 281-307. London: Verso.

Laclau, Ernesto. 2001. Democracy and the Question of Power. Constellations 8 (1): 3-15.

Laclau, Ernesto. 2005. On Populist Reason. London: Verso.

Laclau, Ernesto. 2014. The Rhetorical Foundations of Society. London: Verso.

Laclau, Ernesto and Chantal Mouffe. 1990 [1987]. Post-Marxism without Apologies. In New Reflections on the Revolution of Our Times, Ernesto Laclau, 97-132. London: Verso.

Laclau, Ernesto and Chantal Mouffe. 2014 [1985]. Hegemony and Socialist Strategy: Towards a Radical Democratic Politics, $2^{\text {nd }}$ ed., paperback. London: Verso.

Lukács, Georg. 1971 [1923]. History and Class Consciousness: Studies in Marxist Dialectics. Cambridge: The MIT Press.

Marchart, Oliver. 2004. Politics and the Ontological Difference: On the 'Strickly Philosophical' in Laclau's work. In Laclau: A Critical Reader, edited by Oliver Marchart and Simon Critchley, 54-72. London: Routledge.

Marchart, Oliver. 2007. Post-Foundational Political Thought: Political Difference in Nancy, Lefort, Badiou and Laclau. Edinburgh: Edinburgh University Press.

Marchart, Oliver. 2011. From Media to Mediality: Mediatic (Counter-)Apparatuses and the Concept of the Political in Communication Studies. In Discourse Theory and Critical Media Politics, edited by Lincoln Dahlberg and Sean Phelan, 64-81. Basingstoke: Palgrave Macmillan.

Rancière, Jacques. 1999. Disagreement: Politics and Philosophy. Minneapolis: University of Minnesota Press.

Schou, Jannick, Johan Farkas and Morten Hjelholt. 2015. The Double Conditioning of Political Participation: Grassroots Politics on Facebook. Conjunctions: Transdisciplinary Journal of Cultural Participation 2 (2): 29-47.

Sim, Stuart. 2000. Post-Marxism: An Intellectual History. London: Routledge.

Skeggs, Beverley. 2004. Class, Self, Culture. London: Routledge.

Smith, Anna Marie. 1998. Laclau and Mouffe: The Radical Democratic Imaginary. London: Routledge.

Torfing, Jacob. 1999. New Theories of Discourse: Laclau, Mouffe and Žižek. Oxford: Blackwell Publishers.

Wright, Erik Olin. 2015. Understanding Class. London: Verso.

Wood, Helen and Beverley Skeggs, eds. 2011. Reality Television and Class. London: Palgrave Macmillan.

Žižek, Slavoj. 2000a. Da Capo senza Fine. In Contingency, Hegemony, Universality: Contemporary Dialogues on the Left, Judith Butler, Ernesto Laclau and Slavoj Žižek, 213-262. London: Verso.

Žižek, Slavoj. 2000b. Holding the Place. In Contingency, Hegemony, Universality: Contemporary Dialogues on the Left, Judith Butler, Ernesto Laclau, and Slavoj Žižek, 308-329. London: Verso. 


\section{About the Author}

Jannick Schou

Jannick Schou is a young scholar affiliated with the DECIDIS (Democracy and Citizenship in Digital Society) research initiative at the IT University of Copenhagen, Denmark. His research interests include critical media studies, digital citizenship, and governance. 